The halcyon days are over - or are they? Implications of the global financial crisis for managers' careers.

Dr Teresa Marchant

Lecturer

Graduate College of Management

Southern Cross University

Tweed Gold Coast Campus, PO BOX 42, Tweed Heads, NSW 2485, Australia

E-mail teresa.marchant@scu.edu.au

Date submitted May 292009 


\section{The halcyon days are over - or are they? Implications of the global financial crisis for managers' careers.}

\section{ABSTRACT}

This paper discusses the implications for managers' careers of the global financial crisis. It draws on empirical research during the last period of major job cuts. Evidence comes from a mail survey of over one thousand career histories of Australian managers, with a response rate of 44 percent. Changes to career satisfaction, job satisfaction, job security, expectations regarding future career moves, and employability are reported for retrenched managers. The paper contributes a context for changes to managers' careers in terms of labour market structures and economic conditions. The main results were that following 1990s restructuring, job security was low and retrenched managers were less likely to have invested in their own employability but paradoxically exhibited more of the attitudes associated with employability. The paper is useful for careers practitioners to understand the impacts on managers experiencing job loss and to be aware of possible outcomes and actions required of individuals. 


\section{INTRODUCTION}

A realistic and informed understanding of labour market structures is necessary to comprehend the process of and prospects for managers' careers (Littler \& Innes, 2004). Macro-level trends have micro-level impacts on individuals' careers, and careers discourse should be located in an historical, social, political and economic context (Dyer, 2006), which can add to a social justice perspective (McMahon, Arthur, \& Collins, 2008). Research in job mobility, industrial restructuring, and labor market inequality should be integrated in studying the connection between structural changes and individual behaviors (Shin, 2007). Since we are still in the middle the global financial crisis, no large-scale data on Australian managers is currently available and the nature and cause of job losses is different this time around. Nonetheless we can still learn from past experience. This research is relevant to managers in terms of gaining ideas about what to expect from downsizing, career practitioners such as counsellors, coaches and outplacement advisers who may be working with retrenched managers, and for human resource (HR) practitioners in organisations where surviving managers are affected by what happens to their colleagues. The paper is situated in the body of literature about the effects of organisational restructuring on the careers of individual managers in terms of key variables such as job security, career mobility and satisfaction, the psychological contract, and employability attitudes and behaviours. The paper starts with the context of managers' career over the last fifty years, looks at the consequences of changes in that time, explains the method and results of the survey of Australian managers and then explores the implications for theory and practice in today's environment. 


\section{THE CHANGING ECONOMIC AND ORGANISATIONAL CONTEXT OF}

\section{MANAGERS' CAREERS}

The changing economic and social context of managers' careers can be summarised as follows. The 1950s to 1970s saw a period of growth in large organisations with established, secure, internal labour markets giving opportunities for steady career progression through a series of organisation levels in hierarchical or bureaucratic structures (O’Brien, 1991). The notion of a job for life was not unusual and Whyte's (1958) 'organisation man' typified lifelong employment, security and loyalty to the organisation for white collar workers. When large scale job losses occurred in the 1970s, blue collar workers were the main target as industries suffered recessionary pressures (Cameron, Freeman, \& Mishra, 1991; Farber, 1996). Managers and white collar workers were largely protected.

In the 1980s and 1990s, the shift to the knowledge or information economy saw extensive organisation restructuring, where even white-collar work was elided by technology (Dopson \& Stewart, 1993; Lloyd \& Bridges, 1995; Rifkin, 1995). Downsizing and delayering affect managers' careers, through fewer management levels and fewer managers (Brockner \& Lee, 1995); reducing economic rewards, autonomy, job security and career opportunities (Bamber, 1986). At least half of large organisations in the United States, United Kingdom, New Zealand, South Africa, Canada, and Australia downsized (Littler et al., 1997a; 1997b). Estimates were that 800,000 Australian white-collar jobs were eliminated (Cleary, 1997). Organisations removed whole layers of middle managers, who were pilloried as 'dead wood' or ‘dinosaurs' (Floyd \& Wooldridge, 1994). One of the key points about the 1980s and 
1990s is that restructuring was a strategic initiative rather than a reaction to particular economic shocks or crises. Media attention to this phenomenon was high in the 1990s but waned in the new decade.

In the years 2000 to 2007 downsizing was relatively less prevalent or unpublicised apart from notable instances such as the collapse of Ansett (Weller, 2007). Nonetheless there has been ongoing organisational restructuring (McCann et al., 2008; Zwetsloot, Gort, Steijger, \& Moonen, 2007).

Since the last recession in 1990-1991 Australia has enjoyed a long period of relative wealth and low unemployment, where the biggest issue faced by many organisations has been the lack of skilled labour. The young have never experienced recession and associated job loss. A buoyant economy meant that most felt their jobs were secure and if necessary a new position would be easy to find (Weller, 2007). The Australian Workplace Employment Relations Survey found an increase in satisfaction and security as employers were driven by the skills shortage to improve work conditions (Brown, Forde, Spencer, \& Chartwood, 2008).

For much of the labour market in Australia there was a high level of dynamism with individuals changing from one job to another. However when large shocks happen, job change is more likely to be involuntary (Carroll \& Poehl, 2007). The global financial crisis represents just such a shock. Although media reports of job cuts vary from the numbers that organisations eventually shed (Littler \& Innes, 2004), it is clear that job cuts are happening (Fitzpatrick \& Craig, 2008; Forrestal \& Burrell, 2009; Murdoch, 2008; Murphy, 2009). 
Thus we are once again in an era of downsizing, albeit this time around a reactive response to crisis. Human resource management and development rhetoric about people being the organisation’s most important asset (Holland, Sheehan, \& De Cieri, 2007) and the need for career conducive organisations (Gilbreath, 2008) has been replaced by statements about the need for 'the elimination of approximately 5 per cent of our global workforce' to give one example (Evans, 2009, p. 45). Employees have been reframed from a strategic and scarce asset to something 'to be got rid of'.

\section{IMPLICATIONS FOR INDIVIDUAL MANAGERS}

Downsizing has many implications both for individuals who are retrenched and those who remain in the organisation ('survivors'), including changes to the psychological contract (Bellou, 2007; Rousseau \& Wade-Benzoni, 1995), survivor syndrome (Brockner, et al., 1997), effects on job satisfaction, perceived career promotion opportunities, career mobility (Hirsch \& de Soucey, 2006), options after retrenchment and attitudes about employability.

\section{Psychological contract}

The 'merge and purge syndrome' altered the psychological contract between managers and their organisation (Frohman \& Johnson, 1993, p.75). When such contract expectations are breached employees are more likely to leave or want to leave the organisation (Granrose \& Baccili, 2006). A new type of psychological contract was forecast which was situational, short term, shifting the risk towards employees who are more responsible for managing their position in the labour market 
(Kohlireser \& Shreiber, 2007; Waterman, Waterman, \& Collard, 1994; Wajcman \& Martin, 2001). A new literature emerged on 'new' careers and attitudes such as employability (Arthur \& Rousseau, 1996). Donohue, Donohue, \& Grimer (2007) indicate the psychological contract has not attracted much research attention in Australia. This may well be since the economic boom enjoyed in this country tipped the contract in favour of managers.

\section{Career satisfaction, perceived promotion opportunities and career mobility}

Turning now to other career consequences of downsizing, perceived availability of promotion opportunities is an important part of the psychological contract and has recently been discussed in terms of the quality of work life (Theodossiou \& Zangelidis, 2006) but received relatively little attention in the literature around retention strategies (Rose, Beh, Uli, \& Idris, 2006). Research in the 1990s showed career path consequences associated with restructuring. Career dissatisfaction among managers was widespread, particularly in terms of future promotion prospects (Nicholson, 1993). Despite the apparent widespread effect of organisation restructuring on career satisfaction the topic seems to have had little attention in recent years.

\section{Job security}

Reports on job security in the 1990s indicted that it was perceived as low in Australia (Bagnall, 1996; Littler, 1997). Two large-scale US surveys show that private sector job security decreased between 1973 and 2006 in the US, with shorter job tenure (Farber, 2008) and perceived job security (Fullerton \& Wallace, 2007) with the latter 
attributing this to labour flexibility needs of organisations. Despite this eroding of security it is still considered desirable. For example, the Australian Work and Life Index specifically includes a measure of job security as one aspect of quality work life (Pocock, Williams, \& Skinner, 2007).

In summary there is a long-term, historical, structural and economic perspective that impacts on how managers experience their careers, which transcends any particular individual story. Having reviewed some of this context, the paper turns next to identifying and measuring the effects of job cuts based on responses from individual managers. The objectives of the following analysis and discussion are to:

- establish how managers rated their job security, how satisfied they were with it, and identify the importance attributed by managers to job security.

- identify the effects on job satisfaction for retrenched managers.

- establish how managers perceive their career opportunities and investigate managers' expectations regarding the direction of future career moves.

- explore aspects of employability as the new psychological contract.

\section{METHOD}

The results are based on a national mail survey of 2311 Australian managers conducted in 1997. The survey paralleled previous work in documenting managerial careers (Nicholson \& West, 1988; Inkson, 1995) and the effects of downsizing (Doherty \& Horsted, 1995a; 1995b; 1996) as well as adding new measures on a range of variables. There were 1009 replies, representing a response rate of 44 percent. The 
sample was divided into two groups for analysis: managers who reported redundancy (retrenched, $n=412$ ), and those who did not (continuous careers, $n=597$ ).

A twelve-page questionnaire was pre-tested with a focus group, reviewed by threeway analysis using the Total Design Method (Dillman 1978) and piloted on a group of thirty managers. Well-documented measures published in the literature (Nicholson \& West, 1988; Inkson, 1995) were used to develop questions about career moves. Regarding employability, job security and career expectations, a new scale of fifteen items was constructed. An initial pool of twenty-seven items was generated from the literature, and reduced to twenty-one items after a scrutiny of face validity. Items with low inter-item correlations in the pilot study were eliminated resulting in fifteen. Career path expectations for the next two-and five-years used a variation of questions from an Australian case study (Littler \& Bramble, 1995).

There was no single national sampling frame for managers, therefore, three different ones were used - a random sample drawn from the Australian Institute of Management (AIM) in two states, the Finance Sector Union (FSU) on a national basis, and a database of managers who had been retrenched provided by a large national outplacement firm (DBM Asia Pacific). The sample was large, but not random or representative. Surveys were distributed by mail on behalf of the researcher and all respondents were anonymous, unless they chose to provide their contact details for subsequent follow up.

The sample had a large majority (60 percent) of managers from the finance and insurance industry. Respondents were predominantly male (83 percent) over forty (56 
percent), and employed in large organisations (62 percent with over 1000 employees), in the private sector (86 percent). Tertiary qualifications were held by 47 percent. The most frequently used description of management level was middle manager (38 percent). Results were analysed with SPSS. Despite the relative large sample size, non-parametric tests were used since it could not be assumed the data comes from a normally distributed population, nor was (much of) the data metric (Francis, 2007).

\section{RESULTS}

\section{Low job security}

Lack of job security was felt by many managers, and in particular the retrenched. Only twenty-three percent of retrenched managers and thirty-seven percent of managers with continuous careers felt that their jobs were very secure, as illustrated in Figure 1. There was a significant difference between the two groups in terms of perceived job security, with more retrenched managers reporting their job was not very secure $($ Mean rank Continuous $=448.47$, Retrenched= 523.93, Mann-Whitney U $=90674, \mathrm{~W}=263252, \mathrm{Z}=-4.2480, \mathrm{p} \leq 0.001$, two-tailed).

\section{Figure 1 about here}

It could be concluded that having experienced retrenchment, these managers had a greater appreciation of the fact that jobs were no longer secure. Interestingly, retrenched managers attached less importance to job security (Mean rank Continuous $=440.57$, Retrenched $=$ 571.69, Mann-Whitney $\mathrm{U}=$ 85891.0, $\mathrm{W}=2590579.0, \mathrm{Z}=-$ 7.5607, $\mathrm{p} \leq 0.001$, two-tailed). Satisfaction with job security was quite low, with only 
thirty-two percent of all managers reporting that they were satisfied with their job security. There was no difference between the two groups.

\section{Job Satisfaction}

Retrenched managers who had found a new position were asked to compare job satisfaction in the new position with that in the old. Nearly half (forty-eight percent) reported more job satisfaction. For one quarter (twenty-six percent) it was about the same, and the remaining quarter (twenty-six percent) it was less. A cross-tabulation of job satisfaction by salary explored the relationship between these two outcomes. The figures are given in Table 1, from which it can be seen that higher new salary was significantly associated with higher new job satisfaction $\left(\chi^{2}=18.39\right.$, $\mathrm{df}=4$, 0 . 001).

\section{Table 1 about here}

There was also a significant association between new role and new salary. Those who remained in management were more likely to be earning more than they did previously, whereas those who had moved to consulting or a different role were likely to be earning less, as shown in Table $2\left(\chi^{2}=15.08, \mathrm{df}=4, \mathrm{p} \leq 0.01\right)$.

\section{Table 2 about here}

These results suggest that the best outcome for retrenched managers was to move to another management position, where they were more likely to achieve higher salary, and possibly more job satisfaction. Keep in mind though that only just over half found another management position.

Figure 2 about here 
Managers were asked to report on a series of actions taken to enhance or develop their skills and career in the past year. The results are shown in Figure 2. Retrenched managers reported completing fewer of these activities (mean continuous $=7.23$, mean retrenched 6.90, $\mathrm{df}=1005, \mathrm{t}=3.48, \mathrm{p}<0.001,2$-tailed).

\section{Career satisfaction}

In general, managers were satisfied with their careers to date. However, satisfaction with future career was not particularly high, with only about one-third (thirty-six percent) of all managers indicating satisfaction with career prospects. Compared to managers with continuous careers, the retrenched felt their opportunities would increase in future and were more satisfied with their future prospects, as illustrated in Figure 3.

\section{Figure 3 about here}

Also the retrenched did not feel trapped where they were for the rest of their career as noted below.

\section{Expectations regarding future career mobility}

Managers' were asked whether they expected to be in the same job in two years. If not, they were asked to indicate the status, organisation, or industry changes that they expected to make. About forty-five percent of managers did expect to be in the same job in two years. For those who expected to move, the results are shown in Table 3. There was no significant difference between retrenched and continuous careers.

Table 3 about here 
Since changing employers and changing industry are two key dimensions associated with job change, managers were also asked to give their expectations on these dimensions. The results are shown in Table 4. Thirteen percent of continuous career managers and twenty-seven percent of retrenched managers expected to change organisation. This difference in the mobility expectations of the two groups was significant $\left(\chi^{2}=42.14, \mathrm{df}=3, \mathrm{p} \leq 0.001\right)$. Thus retrenched managers were more likely to expect to change employers in future, demonstrating some aspects of an employability attitude.

\section{Table 4 about here}

This argument, that retrenched managers' career orientation tended towards employability, was supported by other items in the questionnaire. Differences between the two groups on employability attitudes were examined using MannWhitney U-tests. There were differences between the two groups on nine of the fifteen items, as reported in Table 5.

\section{Table 5 about here}

The results indicated that, compared to managers with continuous careers, retrenched managers expected to change jobs in future, did not expect their current job to be their last, and did not expect to have a 'job for life'. They also claimed to be responsible for their own professional development, did not expect the employer to take care of their career, managed their own career, and were developing a portable suitcase of skills. These results indicate that retrenched managers' attitude to their careers was one of employability. 


\section{DISCUSSION}

In terms of the research objectives, this paper found that job security was relatively low in the context of organisation restructuring, as was satisfaction with job security, with some pessimism around future career prospects. Retrenchment reduced managers' dependence on employer-provided job security and career development. The best outcome was to move to another management position, where they were more likely to achieve higher salary, and possibly more job satisfaction. It was a liberating experience for some managers, but not all were able to return to a 'good' job. Perhaps managers who lose their jobs are given an opportunity to change and seek something more satisfying than they might otherwise have initiated for themselves. Retrenchment represents what Kohlireser and Shreiber (2007, p. 2) called a 'moment of truth' provoking a critical career transition. In this study the retrenched managers certainly had different attitudes and outcomes. Although managers' lack of action to improve their employability may have contributed to their demise, job loss could be a critical event in promoting an employability career attitude. However, with around one half going on to another management position it appears that Wajcman and Martin’s (2001) observation that managers still prefer long organisational careers is somewhat supported here. Baruch (2006) also argued that much of what used to apply in terms of traditional careers still does and that a certain level of and desire for security and stability in individuals and organisations means that this situation is likely to continue. 
This research adds to the literature on employability. Employability attitudes and actions can be measured and are useful for distinguishing between groups of managers who experience different career events. The instrument used to measure managers employability actions, such as professional and personal development can be used as a guide or check list to encourage managers to take actions to improve their employability and perhaps avoid retrenchment.

Despite the popular and widespread uptake of the concept of employability in the literature, the evidence that it has been embraced by individuals is at best mixed. The most likely conclusion is that if it has been adopted, it is by younger workers who never experienced the old psychological contract (Patrickson \& Clarke, 2008), although in contrast Hicks (2007) found little or no generational effect on the psychological contract. Further, there is little evidence that organisations encouraged personal development and growth to improve employability, since in a skills shortage, retention and commitment to the organisation is what employers want (Gandolfi, 2006). Encouraging employees to be independent and mobile is counter productive to organisations' retention needs in times of skills shortage. The present study suggests that managers may adopt employability as a reaction to negative events, rather than as a proactive response initiated by their own efforts, or others' exhortations. There is some suggestion that for retrenched managers, an attitude of employability replaced job security. However this change may have come about as a result of loss of faith in, or loyalty to, employers, not because of any constructive action on the part of organisations. 
Employability activities were significant in distinguishing between managers who were retrenched. Many of these activities come under the ambit of human resource development (Werner \& De Simone, 2006) and are advocated as good strategies for organisations to implement in order to retain key staff during skills shortages. Further, organisation support for career development increases employee career satisfaction (Barnett \& Bradley, 2007). Whether organisations do enough of this seems unlikely and this paper argues that individuals should take responsibility for these actions, not only to enhance their career prospects but to insure against being at risk of retrenchment. Social justice suggests organisations should take more responsibility but pragmatics, profits and shareholder pressures likely will out.

Many managers in this study still expected their careers to have an upward trajectory. This is a challenge for organisations with flatter career structures and smaller organisations following job cuts. It seems likely that managers' career development in large organisations will continue to exhibit the patterns found by McCann, Morris, and Hassard (2008) of increasing rewards, responsibility and scope within role, rather than moving up to a higher position in the hierarchy. They concluded that there was little evidence of a wholesale shift away from internal labour markets or evidence of new career types. However their study was limited to managers in six large UK organisations where traditional careers are more likely to be found. The research reported in the present study suggests that it is necessary to study managers who have been retrenched from large organisations in order to find evidence of new career types and attitudes. 


\section{IMPLICATIONS FOR TODAY'S ENVIRONMENT WITH THE GLOBAL FINANCIAL CRISIS}

Since this paper has argued for a contextualised understanding of managers’ careers, consideration must be given to how managers' experiences in the 1990s are comparable to today.There are at least four aspects of context which need to be taken into account. They are the impact of the baby boomers, the skills shortage, the nature of crisis compared to strategic restructuring, and other trends in the structure of work such as the increase in precarious employment.

Baby boomers at work are a paradox, simultaneously representing both a critical success factor and potential drain on organisation performance and financial resources (Callanan \& Greenhaus, 2008). We saw from the results of this study that those who were retrenched tended to be (then) middle aged. This time around will organisations target older managers, or younger ones in whom they have made less investment and who have less experience? It will be interesting to see whether the baby boomers, most recently the subject of discussion in terms of the significance of their retention, phased retirement, and loss of corporate knowledge were targeted compared to younger generations such as the much discussed Gen Y. This research suggests that the biggest factor will be investment in their own development or human capital which contributes to employability. The absence of employability may predict retrenchment, rather than age.

What happens after the global financial crisis is over and the world returns to a growth economy? Will skills shortages once again become and issue and what are the 
implications for managers and organisations that carried out major downsizing? Depending on whether they handle it effectively or not, organisations that downsize may be left with survivor syndrome, disgruntled and insecure employees, pessimistic about future career prospects, a poor culture, a labour market of more independent managers, a longer term skills shortage, less loyalty and a more mobile workforce.

Managers had enjoyed career satisfaction but when faced with organisation restructuring their outlook was not so positive. This suggests that if organisations want to retain vital managers beyond the global financial crisis, reassurance about career prospects could be valuable.

Another contextual difference is that this time job loss is due to a crisis rather than the more strategic restructuring of previous decades. This suggests that the cuts may be across the board, affecting more levels of the organisation. Also, today's middle managers are likely to be more skilled and flexible (McCann, et al., 2008) than the staid, reliable 'dead wood' targetted in the 1990s. Some retrenched managers were able to find a new management position, in some cases with better salary. How likely is this, compared to the less intense and perhaps more orderly downsizing of the last decade? Nowadays work is more contingent or precarious so managers' attitudes about job security may be more accepting of insecurity and thus retrenchment may have less impact.

Questions that need answering after the global financial crisis has played out will include who lost their jobs (in terms of age, gender, level, salary, occupation and so on), why, and what changes in attitudes to careers have emerged (or re-emerged). 


\section{LIMITATIONS AND FURTHER RESEARCH}

One limitation of the present study is that the data was collected in the late 1990s. It would seem like the ideal time to replicate this research and compare managers' responses between the two time periods. The managers in this study are now quite a bit older and there is considerable attention to generational issues in the work place and how different generations have different values and attitudes. Thus these results might be more relevant to older managers.

Until the global financial crisis the effects of downsizing and redundancy received relatively les attention in the literature in this decade. It would seem like perfect timing to replicate this research in the next year or two to compare the impact of downsizing due to ongoing strategic restructuring, with the drastic and rapid loss of jobs that we may witness over the next period. Since the sample was limited to managers in the private sector and in finance there is scope to extend the study to other industries (particularly mining) and the public sector where costs savings and job losses are also likely, due to government budget deficits. Women were also underrepresented in the study and it is likely that these findings are not generalisable to women. Future research could focus on any gender effects in managerial retrenchment.

\section{CONCLUSION}


Managers’ careers have been positively and negatively affected by a series of changes since the 1950s. The causes, nature and consequences have varied depending on the context. It seems very likely that the halcyon days of the last few years will definitely be over for some. Downsizing had differential effects on those who were retrenched compared those who were not, with arguably some better consequences for retrenched who were less dependent on organisations, with more of an employability orientation. Nonetheless not all were able to maintain or improve their position following retrenchment. In the current global financial crisis it is likely that calls for employability, increased mobility and fears about managers' job security will be reprised. On balance, it seems likely that managers would prefer to stay with their current organisation due to a desire for stability, and the social capital invested in the work group. Taking the long view it is easy to be lulled into a false sense of security. An attitude of employability may emerge only after a shock or crisis. However, it is this author's opinion that all individuals should adopt responsibility for their own careers and their own development across the course of a lifetime due to the unpredictable nature of events, and the very predictable nature of extreme capitalism which sees humans as expendable resources.

\section{ACKNOWLEDGEMENTS}

Professors Kerr Inkson, Craig Littler, Margaret Patrickson, and Michael West for ideas, advice and critique of the research, University of Southern Queensland for the research grant, and AIM, DBM, and FSU for supporting data collection. 


\section{REFERENCES}

Arthur, M. B., \& Rousseau, D. M. (1996). The boundaryless career: A new employment principle for a new organizational era. NY: Oxford University Press.

Bamber, G. (1986). Militant managers?. Aldershot: Gower.

Bagnall, D. (1996). Higher anxiety crisis of confidence. The Bulletin, October, 16-18.

Barnett, B. R., \& Bradley, L. (2007). The impact of organisational support for career development on career satisfaction. Career Development International, 12(7), 617-636.

Baruch, Y. (2006). Career development in organizations and beyond: Balancing traditional and contemporary viewpoints. Human Resource Management Review, 16(2), 125-138.

Bellou, V. (2007). Psychological contract assessment after a major organizational change: The case of mergers and acquisitions. Employee Relations, 29(1), 6888.

Brockner, J., \& Lee, R. J. (1995). Career development in downsizing organisations. In M. London (Ed.), Employees, careers, and job creation, (pp. 49-70). San Francisco: Jossey-Bass Publishers.

Brockner, J., Wiesenfeld, B., Stephen, J., Hurley, R., Grover, S., Reed, T., DeWitt, R. L., \& Martin, C. (1997). The effects on layoffs survivors of their fellow survivors’ reactions. Journal of Applied Social Psychology, 27(10), 835-863.

Brown, A., Forde, C., Spencer, D., \& Charlwood, A. (2008). Changes in HRM and job satisfaction, 1998-2004: evidence from the Workplace Employment Relations Survey. Human Resource Management Journal, 18(3), 237-256. 
Callanan, G. A., \& Greenhaus, J. H. (2008). The baby boom generation and career management: A call to action. Advances in Developing Human Resources, 10(1), 70-85.

Cameron, K., Freeman, S. J., \& Mishra, A. (1991). Best practices in white-collar downsizings: Managing contradictions. Academy of Management Executive, 5 57-73.

Carroll, N., \& Poehl, J. (2007). Job mobility in Australia, Economic Research and Analysis Unit, Department of Employment and Workplace Relations. Retrieved 31 March 2009, from http://www.melbourneinstitute.com/hilda/conf/conf2007/HILDA\%20Conf\%2 0Papers\%202007/All\%20Papers/Carroll,\%20Nicholas_final\%20paper.pdf

Cascio, W. F. (1998). Learning from the outcomes. In M. K. Gowing, J.D. Kraft, \& J. C. Quick, (Eds.), The new organisational reality (pp. 55-69). Washington: American Psychological Association.

Clarke, M., \& Patrickson, M. (2008). The new covenant of employability. Employee Relations, 30(2).

Cleary, P. (1997, 20 October). Lost jobs: The downsizing of Australia. The Sydney Morning Herald, p. 16.

Dillman, D. A. (1978). Mail and telephone surveys. New York: Wiley.

Doherty, N., \& Horsted, J. (1995a). Focus on counselling. Northampton: Working Transitions.

Doherty, N., \& Horsted, J. (1995b). Helping survivors to stay on board. Northampton: Working Transitions. 
Doherty, N., \& Horsted, J. (1996). Re-engineering people-the forgotten survivors. Northampton: Working Transitions.

Donohue, W., Donohue, R., \& Grimmer, M. (2007). Research into the psychological contract: Two Australian perspectives. Human Resource Development International, 10(3), 301-318.

Dopson, S., \& Stewart, R. (1993). Information technology, organisational restructuring and the future of middle management. New Technology, Work and Employment, 8(1), 11-20.

Dyer, S. (2006). Critical reflections: making sense of career. Australian Journal of Career Development, 15(1), 28.

Evans, S. (2009, 27 March). Constellation prepares for more job cuts. The Australian Financial Review, p. 45.

Farber, H. S. (1996). The changing face of job loss in the United States, 1981-1993, Industrial Relations Section, Princeton University.

Farber, H. S. (2008). Job Loss and the decline in job security in the United States, Working Paper \#520, Princeton University Industrial Relations Section. Retrieved 3 April 2009, from http://www.irs.princeton.edu/pubs/pdfs/520revised.pdf

Fitzpatrick, D., \& Craig, S. (2008, 13-14 December). Bank of America to cut 35,000 jobs. The Australian, p. 37.

Floyd, S. W., \& Wooldridge, B. (1994). Dinosaurs or dynamos? Recognising middle management's strategic role. Academy of Management Executive, 8(4), 47-57. Forrestal, L., \& Burrell, A. (2009, 27 March). Miners cut more jobs. The Australian Financial Review, p. 5. 
Francis, G. (2007). Introduction to SPSS for Widows. Sydney: Frenchs Forest, NSW.

Frohman, A. L., \& Johnson, L. W. (1993). The middle management challenge: Moving from crisis to empowerment. New York: McGraw-Hill.

Fullerton, A. S., \& Wallace, M. (2007). Traversing the flexible turn: US workers' perceptions of job security, 1977-2002. Social Science Research, 36(1), 201221.

Gandolfi, F. (2006). Personal development and growth in a downsized banking organization: summary of methodology and findings. Human Resource Development International, 9(2), 207-226.

Gilbreath, B. (2008). Creating career-conducive organizations: A primary intervention approach. Advances in Developing Human Resources, 10(1), 8-31.

Granrose, C. S., \& Baccili, P. A. (2006). Do psychological contracts include boundaryless or protean careers? Career Development International, 11(2), 163-182.

Hicks, M. (2007). Generations and the psychological contract: How civil service reform is perceived by public sector workers. Retrieved 3 April from http://etd.lib.fsu.edu/theses_1/available/etd-06202007153645/unrestricted/mhicks072307.pdf

Hirsch, P. M., \& De Soucey, M. (2006). Organizational restructuring and its consequences: rhetorical and structural. Annual Review of Sociology, 32, 171189.

Holland, P., Sheehan, C, \& De Cieri, H, (2007). Attracting and retaining talent: exploring human resources development trends in Australia. Human Resource Development International, 10(3), 247-262.

Inkson, K. (1995). Effects of changing economic conditions on managerial job 
changes and careers. British Journal of Management, 6, 183-194.

Kohlrieser, G., \& Shreiber, N. (2007). Take charge of your career transitions.

Perspectives for Managers, 142, 1-4.

Kramar R. J. (1990). Managers in Australia. Industrial Relations Research Centre, The University of New South Wales, Kensington.

Littler, C. R., \& Bramble, T. (1995). The impact of the continuous improvement program at the Commonwealth Bank. Paper presented at the Organisational Restructuring in the Service Sector Conference, Department of Industrial Relations, Brisbane.

Littler, C. R., Dunford, R., Bramble, T., \& Hede, A. (1997a). The dynamics of downsizing in Australia and New Zealand. Asia Pacific Journal Of Human Resources, 35(1), 65-79.

Littler, C. R., \& Innes, P. (2004). The paradox of managerial downsizing. Organization Studies, 25(7), 1159-1184.

Littler, C. R., Wiesner, R., Vermeulen, L., Dunford, R., \& Bramble, T. (1997b). The effects of downsizing: Cross-cultural data from three countries. 1997 Academy of Management Meeting. Boston: Academy of Management.

Lloyd, B., \& Bridges, W. (1995). The end of the job. The International Journal of Career Management, 7(2), 29-33.

McCann, L., Morris, J., \& Hassard, J. (2008). Normalized intensity: The new labour process of middle management. Journal of Management Studies, 45(2), 343371. 
McMahon, M., Arthur, N., \& Collins, S. (2008). Social justice and career development: views and experiences of Australian career development practitioners. Australian Journal of Career Development, 17(3), 15-25.

Moskal, B. S. (1995). Promotions: Who gets them and why. Industry Week, 244(5), 44-47.

Murdoch, S. (2008, 6-7 December). ANZ to shed 800 workers. The Australian, p. 2.

Murphy, J. (2009, 10 February ). Nissan to slash jobs in global survival plan. The Australian, p. 23.

Nicholson, N. (1993). Purgatory or place of safety? The managerial plateau and organisational age-grading. Human Relations, 46(12), 1369-1390.

Nicholson, N., \& West, M. (1988). Managerial job change: Men and women in transition. London: Cambridge University Press.

O'Brien, B. A. (1991). An exploratory study of the career aspirations, career progression, and career mobility of ten executives at mid-life. Doctoral Dissertation, UMI.

Pocock, B., Williams, P., \& Skinner, N. (2007). The Australian Work and Life Index (AWALI): Concepts, methodology and rationale, Centre for Work + Life, Hawke Research Institute for Sustainable Societies, University of South Australia. Retrieved 3 April 2009, from http://www.unisa.edu.au/hawkeinstitute/cwl/documents/awali-concepts.pdf

Rifkin, J. (1995). The end of work. New York: The Putnam Berkeley Group.

Rose, R. C., Beh, L. S., Uli, J., \& Idris, K. (2006). Quality of work life: Implications of career dimensions. Journal of Social Sciences, 2(2), 61-76. 
Rousseau, D. M., \& Wade-Benzoni, K. A. (1995). Changing individual organisation attachments. in A. Howard (Ed.), The changing nature of work (pp. 290-322). San Francisco: Jossey-Bass.

Shin, T. J. (2007). The impact of structural dynamics on job mobility rates in the United States. Social Science Research, 36(4), 1301-1327.

Theodossiou, I., \& Zangelidis, A. (2006). Do career prospects make happy workers? evidence from panel data. Business School Working Paper Series 2006-04. University of Aberdeen Business School. Retrieved 5 April 2009, from http://hdl.handle.net/2164/93

Wajcman, J., \& Martin, B. (2001). My company or my career: managerial achievement and loyalty. The British Journal of Sociology, 52(4), 559-578.

Waterman, R. H., Waterman, J. A., \& Collard, B. A. (1994). Toward a career-resilient workforce. Harvard Business Review, 87-95.

Weller, S. (2007). The other side of precariousness: The cost of job loss, Working Paper No. 34, Centre for Strategic Economic Studies, Victoria University. Retrieved 3 April 2009, from http://www.cfses.com/documents/wp34.pdf

Werner, J. M., \& DeSimone, R. L. (2006). Human resource development. (4th ed.), Melbourne: Thomson South-Western.

Whyte, W. H. (1958). The organisation man. New York: Simon \& Schuster.

Zwetsloot, G. I. J. M., Gort, J., Steijger, N., \& Moonen, C. (2007). Management of change: Lessons learned from staff reductions in the chemical process industry. Safety Science, 45(7), 769-789. 


\section{THEORY AND PRACTICE}

1 How would you summarise the overall context and influences on managers' careers since the 1950s?

For the first 20 years managers enjoyed relative security and growth options in their careers as large organisations developed. Even in the 1970s, they were largely protected from layoffs. The next two decades saw organisation restructuring where managers were targetted for the first time. Following a period of economic boom in the early years of 2000 it seems managers careers are now likely to be at risk in the global financial crisis.

2 In what ways are managers' careers likely to be impacted by the global financial crisis?

There is no doubt that managers will be retrenched. Some may be able to find good new management positions but others will move into consulting, smaller organisations or other options which may be less favourable in terms of income and satisfaction. Some are likely to adopt a more independent attitude, realising that they can or should no longer rely on organisations to manage and develop their career or provide them with job security.

3 What were the main career development or human resource development activities that 'protected' managers from retrenchment?

Actions such as performance appraisal, personal and professional development, skills training, mentoring and coaching distinguished the retrenched from those with continuous careers. In other words, human resource development activities to improve 
their personal and professional competence, or increase their human capital offered some insurance against retrenchment.

$4 \quad$ What are some of the attitudes associated with employability and who is more likely to display them?

Attitudes included being responsible for their own career, being prepared to move, feeling free to change jobs and being loyal to themselves. The evidence is inconclusive but the literature suggests the young may be more likely to have this approach to their career, and this research showed it manifested amongst the retrenched. 
Figure 1: Perceptions of Job Security

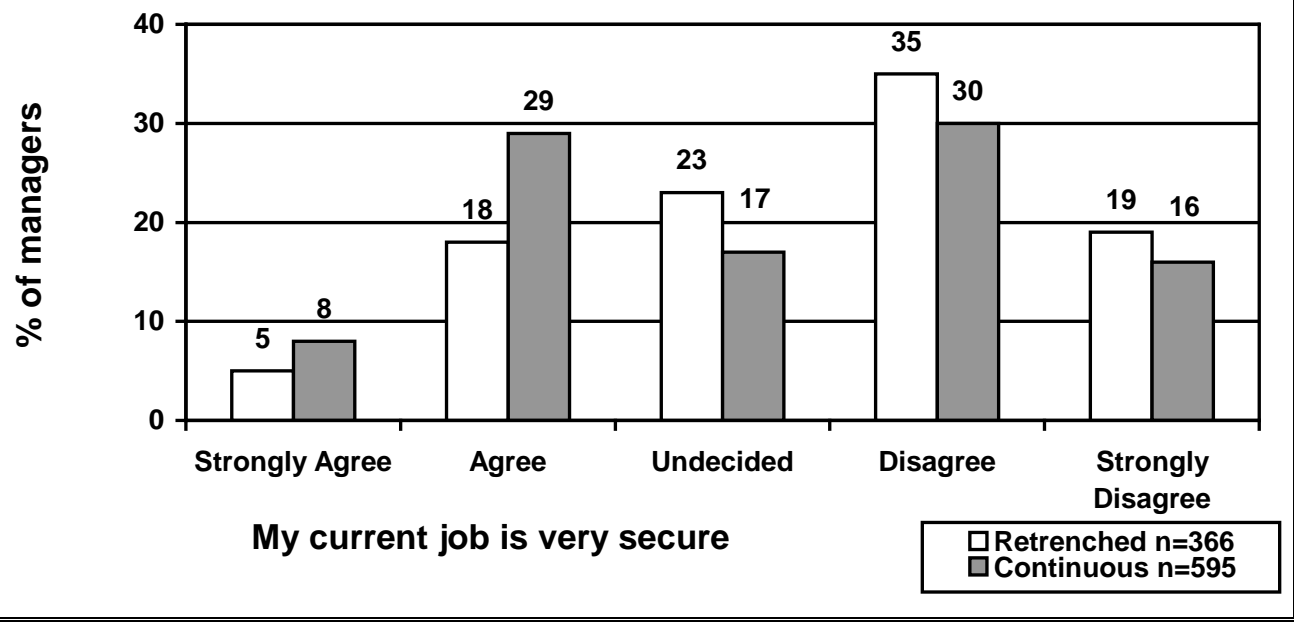


Figure 2: Retrenched Managers Invested Less in their Employability in the

\section{Preceding Year}

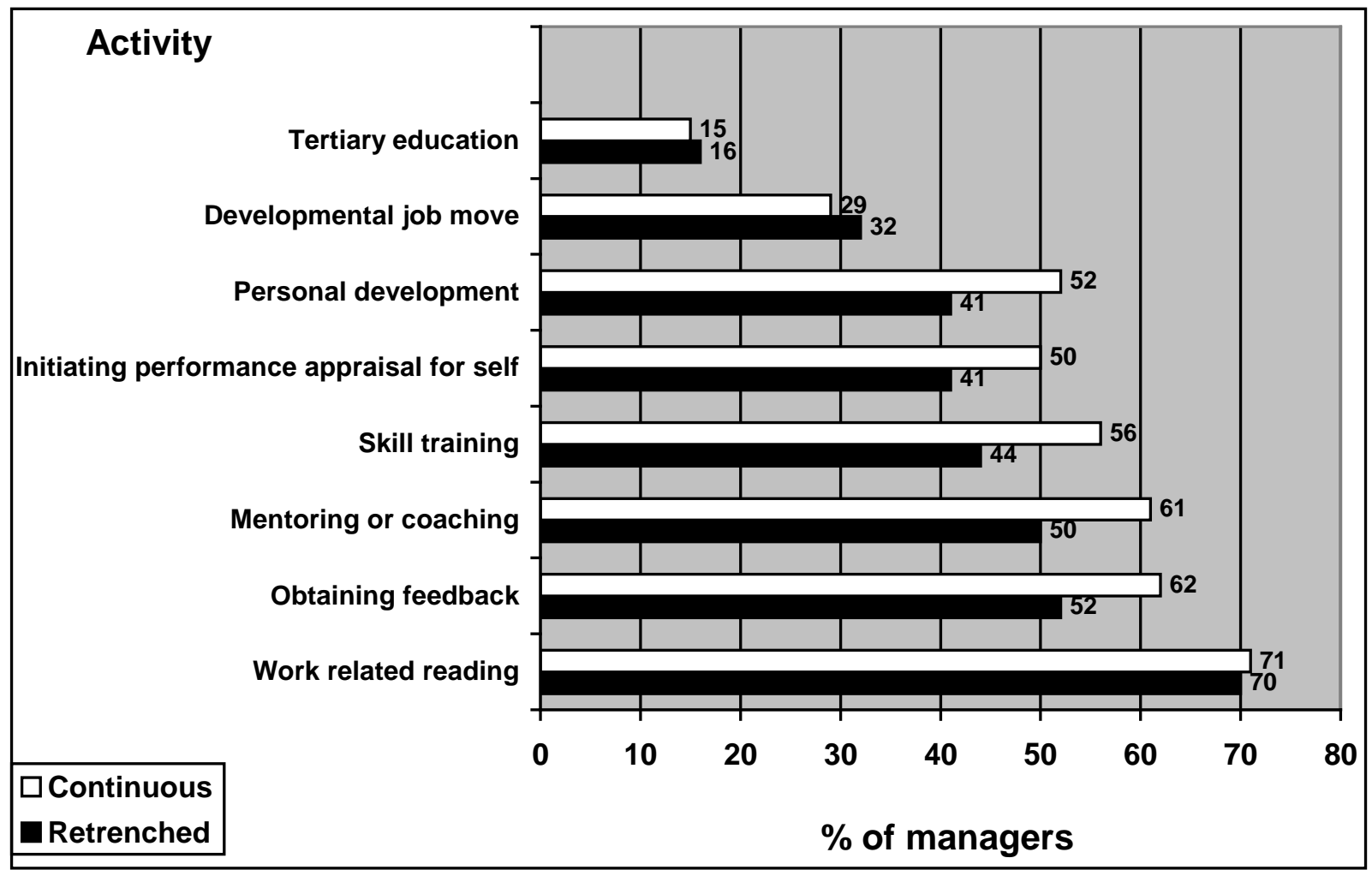


Figure 3: Satisfaction with Career Prospects

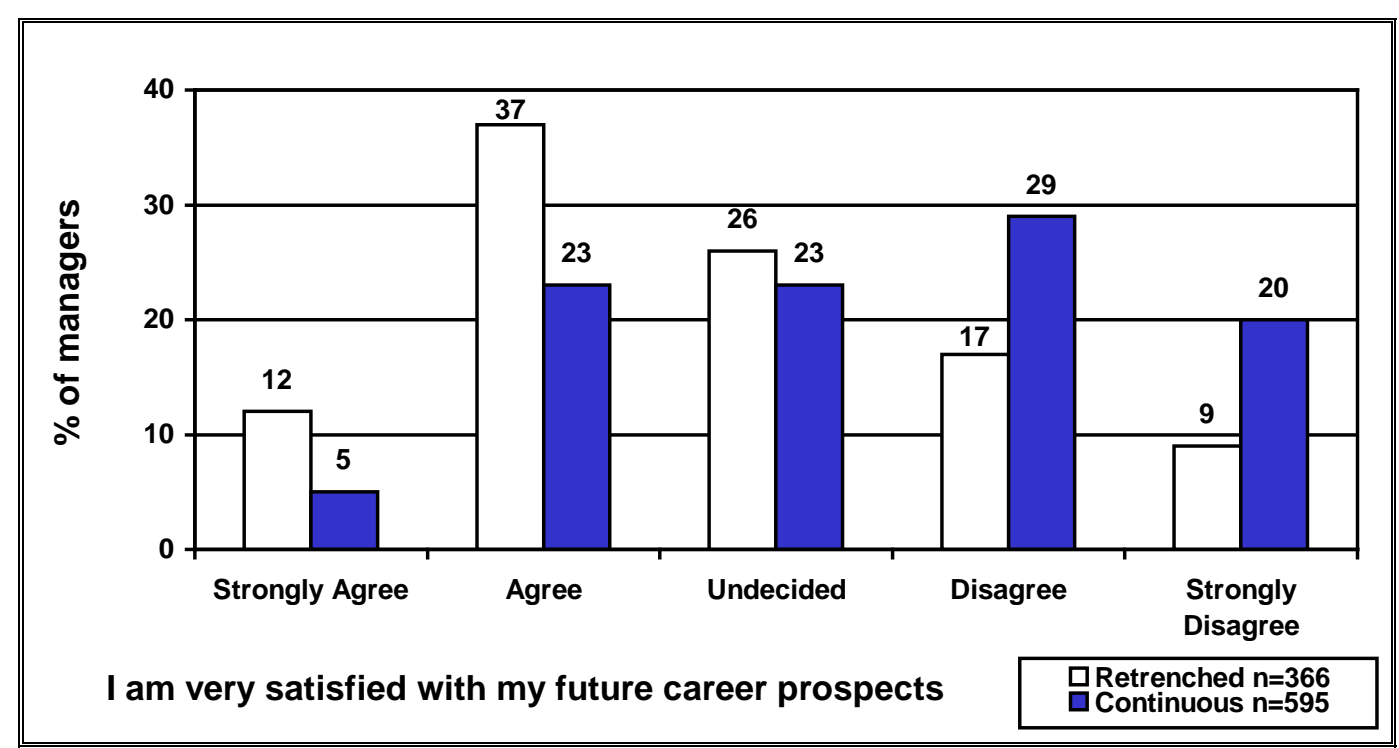


Table 1: Higher Salary was Associated with More Job Satisfaction in the New

\section{Position for Retrenched Managers}

\section{New salary}

$\begin{array}{llll}\text { New job } & \text { Less n (\%) } & \text { Same n (\%) } & \text { More n (\%) } \\ \text { satisfaction }\end{array}$

$\begin{array}{lcccc}\text { Less } & 37(51) & 24(33) & 12(16) & 73(26) \\ \text { Same } & 25(34) & 29(39) & 20(27) & 74(26) \\ \text { More } & 37(27) & 42(31) & 56(42) & 135(48) \\ \text { Total } & 99(35) & 95(34) & 88(31) & 282(100)\end{array}$


Table 2: Higher Salary was Associated with another Management Position for

\section{Retrenched Managers}

\section{Salary}

New Title $\quad$ Less n (\%) $\quad$ Same n (\%) $\quad$ More n (\%) $\quad$ Total n (\%)

$\begin{array}{lcccc}\text { Manager } & 42(26) & 60(37) & 60(37) & 162(57) \\ \text { Consultant } & 36(43) & 27(33) & 20(24) & 83(29) \\ \text { Other } & 20(54) & 9(24) & 8(22) & 37(13) \\ \text { Total } & 98(35) & 96(34) & 88(31) & 282\end{array}$


Table 3: Direction of Expected Career Moves in Two Years Time

\section{Direction}

Up

Down

Lateral

Other

\section{Retrenched \%}

$(n=412)$
Continuous \%

$(n=595)$
55

46

9

8

26

31

10 
Table 4: Expected Career Moves in Two Years Time

\section{Continuous \% $\quad$ Retrenched \%}

$(n=349) \quad(n=245)$

Same organisation

Different organisation

Different industry

Other (including retired, self-employed)
56

13

27

17

28

15

12 
Table 5: Differences between Retrenched Managers and those with Continuous

Careers on Employability Attitude Items*

\begin{tabular}{llllll}
\hline Item & Mean rank & Mean rank & Mann- & W & Z \\
& continuous & retrenched & Whitney & &
\end{tabular}

$\mathbf{U}$

\begin{tabular}{lccccc}
\hline $\begin{array}{l}\text { Expected to change } \\
\text { occupation in future }\end{array}$ & 524.82 & 446.27 & 98263.0 & 178063.0 & -4.4145 \\
Did not expect their & 467.70 & 517.40 & 102084.0 & 274075.0 & -2.7836
\end{tabular}

current job to be their

last

Did not expect to

548.16

414.08

$85459.0 \quad 165259$

$-7.5970$

have a job for life

Claimed to be

515.12

461.70

$104417.0 \quad 184217.0$

$-3.3450$

responsible for their

own professional

development

Did not expect their

452.99

548.48

$93463.5 \quad 265454.5$

$-5.4656$

employer to take care

of their career

Were developing a

541.87

418.69

$87239.0 \quad 166640.0$

$-7.2059$

portable suitcase of

skills 
Felt their career

547.41

413.85

85310.5

164711.5

$-7.4095$

opportunities would

increase in future

Feel trapped here for

434.59

561.73

82371.0

255537.0

$-7.1892$

the rest of their career

Were more satisfied

549.92

407.24

$82661.0 \quad 161267.0$

- 7.9459

with their future

career prospects

* Two-tailed Mann-Whitney U-tests for all items, $\mathrm{p}<0.0001$. 